\title{
Application of Double Different Tomography Method To Determine The 3D of Seismic Wave Velocity Structure in GoLF Geothermal Field
}

\author{
Aplikasi Metode Tomografi Double Difference Untuk Menentukan Struktur Kecepatan Gelombang
}

Seismik 3D Lapangan Panas Bumi GoLF

\author{
Kana A. Natania ${ }^{1 *}$,David P. Sahara ${ }^{2}$, Andri D. Nugraha ${ }^{2}$, Irvan Ramadhan ${ }^{3}$ \\ ${ }^{1}$ Program Studi Teknik Geofisika, Fakultas Teknik Pertambangan dan Perminyakan, ITB, Jl. Ganesha No. 10 Bandung 40132, Indonesia. \\ ${ }^{2}$ Kelompok Keahlian Geofisika Global, Fakultas Teknik Pertambangan dan Perminyakan, ITB, Ganesa 10, 40132. Indonesia \\ ${ }^{3}$ PT. Supreme Energy, Menara Sentraya floor 23th, Jakarta, Indonesia \\ *Email: nataniakana@gmail.com
}

Submit 10-02-2018; Revised 03-03-2018; Accepted 06-03-2018

\begin{abstract}
GoLF geothermal field is located in South Solok Regency, $150 \mathrm{~km}$ SE of Padang city, West Sumatra. Geology, geochemistry and geophysical surveys had been conducted since 2008. Geophysical survey which had been performed including microseismic and magnetotelluric surveys. Seismic velocity structure modelling need to be conducted in order to characterize geothermal reservoir. This study uses microseismic data recorded from 36 seismometers which installed in two time recording time ranges; from September 2010 to April 2011 and from September 2012 to December 2013, with microseismic events recorded respectively 135 and 2692 events. To maximize the result of picking waveform, the data is processed using the Master Event Cross Correlation method to update the catalog data and get more accurate arrival time. Furthermore, the author used TomoDD software to produce hypocenter relocation and the $3 D$ velocity structure under GoLF's geothermal reservoir. The results of the $3 D$ velocity model can be used to determine the structure and phase of the fluid under GoLF geothermal field.
\end{abstract}

Keywords: Geothermal, Microseismic, TomoDD, Master Event Cross Correlation.

Abstrak: Lapangan Panas Bumi GoLF terletak di Kabupaten Solok Selatan, $150 \mathrm{~km}$ arah Tenggara dari kota Padang, Sumatera Barat. Kegiatan eksplorasi geologi, geokimia dan geofisika di lapangan tersebut telah dilakukan sejak tahun 2008. Beberapa survei geofisika yang telah dilakukan diantaranya survei Mikroseismik dan Magnetotellurik. Pemodelan struktur kecepatan gelombang seismik di lapangan panas bumi GoLF diperlukan untuk membantu mengkarakterisasi reservoir panas bumi di daerah tersebut. Penelitian ini menggunakan data hasil perekaman gempa mikro dari 36 buah seismometer yang dipasang dalam dua rentang waktu perekaman: September 2010 sampai April 2011 dan September 2012 sampai Desember 2013, dengan jumlah masing-masing kejadian yang terekam sejumlah 135 dan 2692 kejadian. Untuk memaksimalkan hasil pick- ing waveform maka data tersebut diolah menggunakan metode Master Event Cross Correlation yang selanjutnya digunakan untuk memperbaharui data katalog sehingga didapatkan waktu tiba gelombang yang lebih akurat. Pengolahan data selanjutnya menggunakan perangkat lunak TomoDD untuk menghasilkan relokasi hiposenter dan struktur kecepatan 3D di reservoir lapangan panas bumi GoLF. Hasil dari model kecepatan 3D tersebut dapat digunakan untuk mengetahui struktur dan fase fluida yang terkandung di bawah permukaan lapangan panas bumi GoLF.

Katakunci: Geotermal, Mikroseismik , TomoDD, Master Event Cross Correlation.

\section{PENDAHULUAN}

Indonesia merupakan negara yang kaya akan sumber daya panas bumi, sekitar $40 \%$ cadangan energi geothermal dunia terletak di bawah tanah Indonesia. Saat ini, Indonesia hanya menggunakan 4-5\% dari kapasitas geothermalnya. Kementrian Energi dan Sumber Daya Mineral Pemerintah Indonesia menyatakan bahwa potensi energi panas bumi yang dimiliki oleh Indonesia mencapai sekitar 28.000 MW dengan potensi sumber daya tersebar di 265 lokasi di seluruh Indonesia (Purnomo dkk., 2015).

Lapangan panas bumi GoLF terletak di Kabupaten Solok Selatan, $150 \mathrm{~km}$ ke arah Tenggara dari kota Padang, Sumatera Barat. Di daerah GoLF, Sesar Besar Sumatra melebar menjadi dua segmen utama sesar geser menganan yaitu, Segmen Suliti di daerah utara dan Segmen Siulak di daerah Selatan (Situmorang dkk., 2014). Keberadaan sistem panas bumi GoLF ditandai dengan kemunculan fumarol dan kolam air panas. Fumarol berlokasi di daerah selatan dan area berelevasi tinggi, sementara kolam air panas berlokasi di daerah utara dan area berelevasi rendah. Survei geosains yang talah dilakukan di lapangan in sejak tahun 2008 meliputi survey geologi, geokimia dan geofisika (Sapu- 


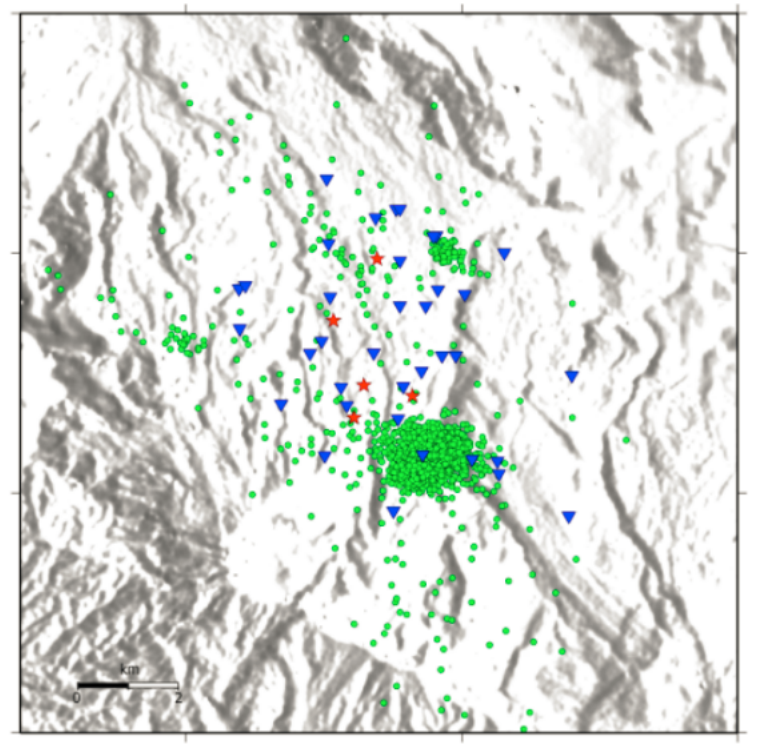

Gambar 1. Persebaran gempa mikro dan stasiun di lapangan panas bumi GoLF. Bulat hijau merupakan persebaran episenter gempa mikro, segitiga terbalik berwarna biru merupakan stasiun dan bintang merah merupakan well.

tra dkk., 2013). Perekaman gempa mikro di lapangan ini dilakukan sebanyak dua rentang waktu, tahap pertama dilaksanakan pada tahun 2010 sampai 2011 dan tahap kedua pada tahun 2012 hingga 2013. Melalui survei mikroseismik diharapkan daerah yang memiliki permeabilitas yang tinggi dapat teridentifikasi.

Data gempa mikro hasil perekaman digunakan dalam pembuatan struktur kecepatan gelombang seismik 3D dengan menggunakan Metode Tomografi Double Difference, sebelumnya dilakukan pembaharuan terhadap data katalog gempa mikro dengan menggunakan Master Event Cross Correlation agar didapatkan waktu tiba gelombang yang lebih akurat. Hasil dari rekonstruksi model kecepatan 3D dapat digunakan untuk menetnukan struktur bawah permukaan serta fasa fluida di reservoir panas bumi GoLF.

\section{DATA DAN METODA}

Penelitian ini menggunakan data waveform dalam format Reftek 301 dan data katalog gempa mikro hasil pengolahan data oleh Institute of Earth Science And Engineering (IESE) dan internal PT Supreme Energy. Data katalog tersebut terdiri dari nomor event, koordinat hiposenter, kedalaman, magnitudo serta juga dilengkapi dengan selisih waktu tempuh dari tiap event ke stasiun yang merekam event tersebut. Total event gempa mikro yang berhasil direkam berjumlah 2827 event, yang berasal dari dua rentang waktu survei. Survei pertama diadakan pada rentang waktu pertengahan September 2010 sampai akhir April 2011 direkam oleh 13 stasiun (135 event). Survei kedua dilakukan pada pertengahan Oktober 2012 sampai akhir tahun 2013 dengan tujuan melihat persebaran event saat aktivitas pemboran eksplorasi dilaksanakan dan direkam oleh 23 stasiun (2692 event).

Model kecepatan 1D yang digunakan merupakan model kecepatan hasil pengolahan dari IESE. Model kecepatan
Tabel 1. Model Kecepatan 1D

\begin{tabular}{|l|l|r|r|r|r|}
\hline $\begin{array}{l}\text { Layer } \\
\text { ke- }\end{array}$ & $\begin{array}{l}\text { Top } \\
\text { Depth } \\
(\mathrm{Km})\end{array}$ & $\begin{array}{r}\mathrm{Vp} \\
(\mathrm{Km} / \mathrm{det})\end{array}$ & $\begin{array}{r}\mathrm{Vs} \\
(\mathrm{Km} / \mathrm{det})\end{array}$ & $\mathrm{Vp} / \mathrm{Vs}$ & $\begin{array}{r}\text { Keteba- } \\
\text { lan }\end{array}$ \\
\hline 1 & -2 & 3.45 & 1.92 & 1.8 & 1.7 \\
\hline 2 & -0.3 & 4 & 2.22 & 1.8 & 1.5 \\
\hline 3 & 1.2 & 4.3 & 2.39 & 1.8 & 4.9 \\
\hline 4 & 6.1 & 6.2 & 3.44 & 1.8 & 8 \\
\hline 5 & 14.1 & 8 & 4.44 & 1.8 & \\
\hline
\end{tabular}

ini ditentukan berdasarkan distribusi event, distribusi stasiun, metode inversi dan parameter yang digunakan. Versi ini merupakan hasil akhir perhitungan setelah optimasi dari versi sebelumnya, menggunakan algoritma genetik dan hasil perekaman data dua periode 2010-2011 dan 2012- 2013. Model kecepatan ini memiliki nilai residual yang kecil.

\section{PENGOLAHAN DATA}

Proses pengolahan diawali oleh proses konversi data waveform dari format Reftek menjadi format .SAC menggunakan perangkat lunak Reftek Converter sehingga memudahkan dalam pengolahan data lebih lanjut. Setelah itu katalog data yang diperoleh diperbaharui dengan menggunakan metode Master Event Cross Correlation untuk memaksimalkan data hasil picking terdahulu. Master Event yang dipilih memiliki kualitas A dan B pemilihan tersebut berdasarkan data katalog terdahulu. Kualitas waveform A dan B ditentukan berdasarkan hasil perhitungan yang memiliki nilai RMS kecil dari hasil picking terdahulu, serta waveform yang berjarak dekat dengan stasiun yang merekam event tersebut. Pemilihan master event juga memperhatikan besarnya magnitudo yang dihasilkan, agar waveform yang dipilih memiliki sinyal yang jelas. Parameter yang digunakan dalam proses ini menggunakan window $0.2 \mathrm{~s}$ dengan setiap pergeseran sebesar $0.05 \mathrm{~s}$ dan dilakukan pemilihan ambang batas/threshold dengan nilai korelasi silang sebesar 0.74 . Master Event Cross Correlation dilakukan pada waveform dengan kualitas A dan B sesuai data katalog pada 16 stasiun.

Data input yang harus dipersiapkan untuk proses tomografi double difference antara lain data katalog absolut, data katalog diferensial, model kecepatan $\mathrm{Vp}$ dan rasio $\mathrm{Vp} / \mathrm{Vs}$, serta parameter grid blok 3D. Data waktu tiba gelombang diferensial merupakan data katalog travel time yang sudah berpasangan antara satu event dengan event yang lainnya melalui program ph2dt. Parameter yang digunakan pada program ph2dt yaitu jarak maksimum antar pasangan event dengan stasiun (MAXDIST) sebesar $10 \mathrm{~km}$, jarak maksimum antar event yang berpasangan (MAXSEP) sebesar 2 $\mathrm{km}$, jumlah maksimum tetangga gempa mikro (MAXNGH) sebesar 10 jumlah minimum link yang dibutuhkan untuk mendefinisikan tetangga (MINLNK) sebesar 8 (Waldhauser, 2001).

Dalam penentuan struktur kecepatan 3D, dilakukan penentuan titik-titik grid nodes yang akan diinversi untuk mengetahui perubahan kecepatannya. Grid nodes ditentukan berdasarkan posisi stasiun dan sebaran hiposenter. Dalam menentukan ukuran grid digunakan jarak 1x1x1 km pada area persebaran episenter gempa mikro. Jumlah grid 


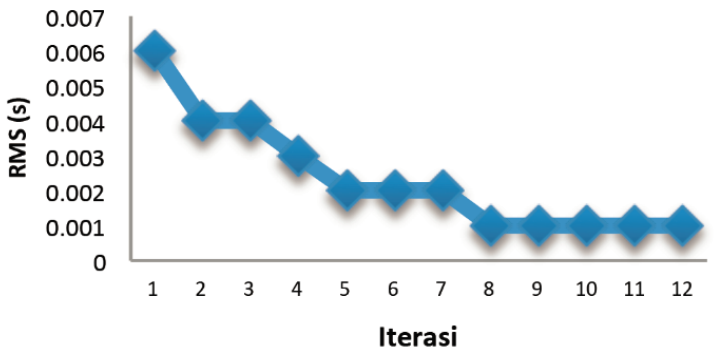

Gambar 2. Hubungan Banyaknya Iterasi dengan nilai RMS hasil inversi.

dalam sumbu X sebanyak 17, sumbu Y sebanyak 17, dan pada sumbu $\mathrm{Z}$ sebanyak 15 .

Dalam proses inversi TomoDD, terdapat beberapa parameter penting yang perlu ditentukan yaitu bobot untuk masing-masing fasa, skema pembobotan untuk data kata$\log$ absolut dan diferensial, dan damping. Bobot fasa yang digunakan dalam penelitian ini yaitu 1 untuk fasa $\mathrm{P}$ dan 0,75 untuk fasa S. Bobot tersebut dipilih karena penentuan waktu tiba fasa $\mathrm{S}$ memiliki ketidakpastian yang lebih besar dibanding penentuan waktu tiba fasa P. Selanjutnya untuk pembobotan data katalog absolut dan diferensial Zhang dan Thurber (2003) menyarankan untuk memberikan bobot yang lebih besar pada data absolut di awal inversi untuk mendapatkan struktur kecepatan di luar daerah sumber gempa mikro. Di akhir inversi, bobot yang lebih besar diberikan untuk data diferensial untuk memperbaiki struktur kecepatan di daerah sumber gempa mikro. Pada penelitian ini, kami menggunakan 3 skema pembobotan sebagai berikut pada awal inversi diberikan pembobotan terhadap data katalog absolut sebesar 10:1 terhadap data diferensial diikuti dengan pembobotan yang setara antara data katalog absolut dan diferensial yaitu 1:1, dan diakhir inversi, skema pembobotan untuk data diferensial diperbesar sehingga bobot katalog absolut dan diferensial menjadi 1:10.

Pemilihan damping pada inversi TomoDD melihat nilai conditional number (CND) untuk menunjukkan kestabilan inversi. Rentang nilai CND yang disarankan oleh Waldhauser (2001) adalah 40-80. Nilai CND bergantung dengan damping, sehingga nilai damping diatur sesuai dengan rentang CND untuk inversi yang stabil. Selain itu, jumlah dan sebaran data juga berpengaruh terhadap damping. Nilai CND yang digunakan sebesar 90 dan 105. Banyaknya iterasi juga memperhitungkan besarnya RMS yang dihasilkan. Pada Gambar 2 terdapat hubungan antara banyaknya iterasi dan nilai RMS yang turun dari 0.006 detik menjadi 0.001 detik. Perubahan nilai RMS tersebut menuju suatu nilai atau menjadi konvergen.

Pada penelitian kali ini kami menggunakan Checkerboard test dan Derrivative Weight Sum untuk uji resolusi. Checkerboard test merupakan teknik untuk melihat hasil inversi pada seluruh ruang model. Tes ini dilakukan dengan menggunakan sinar gelombang seismik dari sumber gempa mikro ke stasiun penerima dengan menggunakan data hasil pengukuran di lapangan melalui medium kecepatan sintetik. Checkerboard test yang digunakan memiliki perturbasi sebesar 20\%, sedangkan Derrivative Weight Sum atau DWS merupakan banyaknya raypath yang melewati area tertentu. Banyaknya raypath dapat menentukan daerah interpretasi.
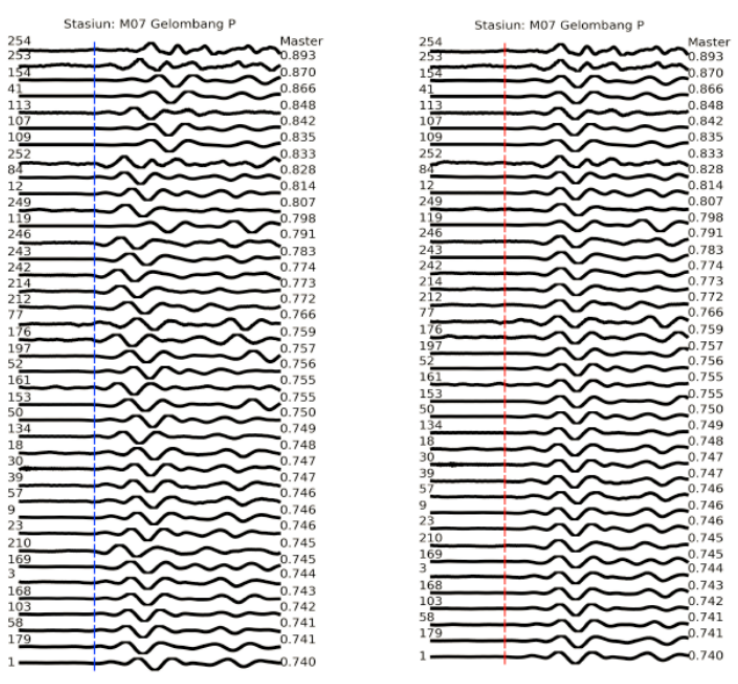

Gambar 3. Hasil Master Event Cross Correlation untuk fase gelombang $\mathrm{P}$; sebelum dilakukan WCC (kiri), dan setelah dilakukan WCC (kanan)

Semakin besar raypath yang melewati daerah tersebut nilai DWS akan semakin besar. Batas nilai DWS yang digunakan adalah 500 karena saat nilai 500 di daerah tersebut memiliki daerah irisan yang sama dengan hasil Checkerboard Test yang dapat di interpretasi.

\section{HASIL DAN ANALISIS}

\subsection{Update Catalog Data}

Berdasarkan update data katalog menggunakan master event cross correlation dengan nilai threshold 0.74 maka diperoleh total fase gelombang $\mathrm{P}$ dan $\mathrm{S}$ yang di update sebesar 694 untuk fase P dan 771 untuk fase S. Banyaknya gelombang $\mathrm{P}$ dan $\mathrm{S}$ yang terupdate pada tiap stasiun tidak sama karena bergantung dari waveform tiap stasiun dan kemiripan sumber dengan master event. Gambar 3 merupakan perubahan picking arrival time $\mathrm{P}$ sebelum dan sesudah dilakukan metode master event cross correlation, dapat dilihat setelah dilakukan WCC picking waktu tiba gelombang $\mathrm{P}$ menjadi lebih baik.

\subsection{Relokasi hiposenter}

Pengolahan data untuk relokasi hiposenter dan struktur kecepatan 3D menggunakan perangkat lunak TomoDD. Secara statistik hasil relokasi gempa mikro dengan perangkat lunak TomoDD menunjukkan peningkatan jumlah gempa mikro yang memiliki nilai RMS kecil. Pada Gambar 4 terlihat histogram RMS data katalog memiliki rentang RMS 0.01 s sampai $0.1 \mathrm{~s}$ dengan dominan $0.02 \mathrm{~s}$, selanjutnya historagm RMS hasil relokasi TomoDD menunjukan rentang RMS yang semakin kecil dan memiliki dominasi di nilai $0.01 \mathrm{~s}$.

Hasil relokasi gempa mikro dengan menggunakan perangkat lunak TomoDD ditunjukkan oleh Gambar 5. Persebaran hiposenter gempa mikro membentuk suatu kluster di sekitar sumur pemboran. Persebaran gempa mikro 


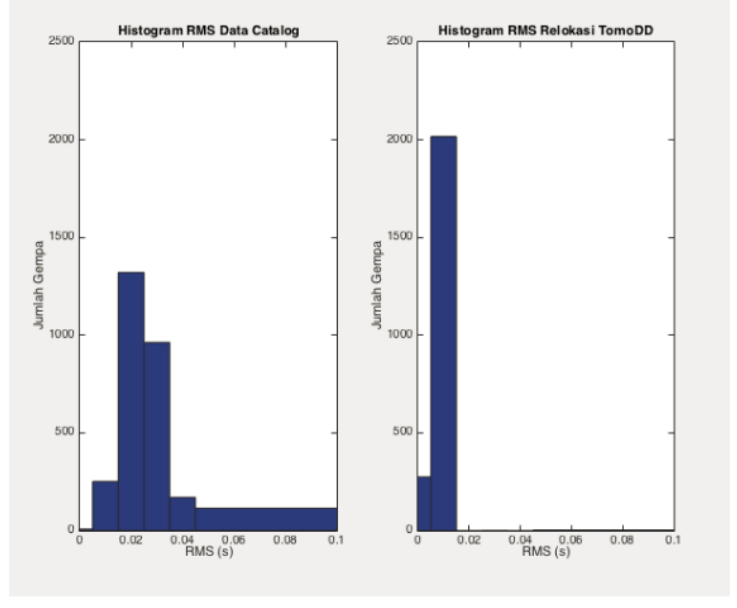

Gambar 4. Histogram perbandingan RMS catalog data sebelum relokasi (kiri) dan setelah relokasi dengan TomoDD (kanan).

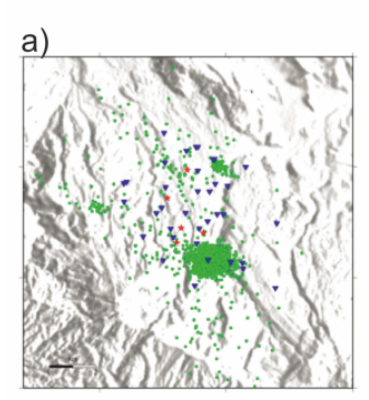

C)
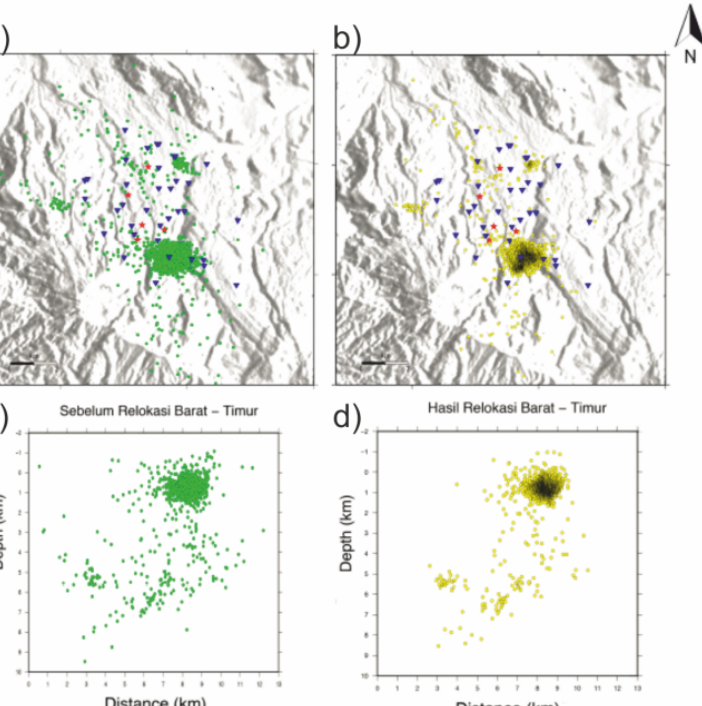

d).

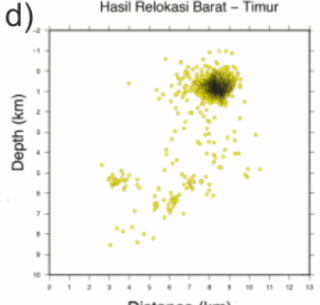

Distance $(\mathrm{km})$ a) $\mathrm{Z}=-1 \mathrm{~km}$

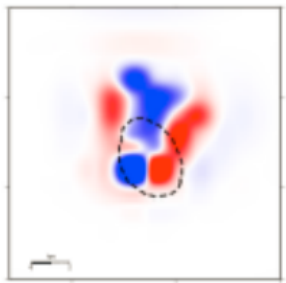

a)

$\mathrm{Z}=0 \mathrm{~km}$

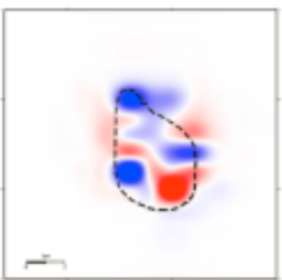

a)

$\mathrm{Z}=1 \mathrm{~km}$

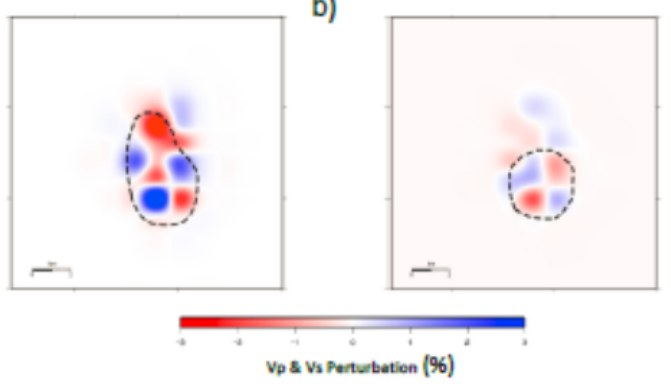

Gambar 6. Tomogram a) Vp dan b) Vs dan pada kedalaman $\mathrm{Z}=$ -1 , 0, dan $1 \mathrm{~km}$ msl. Garis hitam putus-putus merupakan overlay dengan nilai DWS 500.

Resolusi tomogram Vp lebih baik karena fasa $\mathrm{P}$ lebih banyak dibandingkan fasa $\mathrm{S}$.

\subsection{Hasil Inversi Tomografi} nakan TomoDD (kanan). Bulat hijau merupakan episenter gempa sebelum relokasi, bulat kuning merupakan episenter gempa setelah relokasi, segitiga biru terbalik merupakan stasiun, dan bintang merah merupakan sumur pemboran.

yang membentuk kluster tersebut menunjukkan bahwa aktivitas pemboran pada lapangan panas bumi GoLF menyebabkan terbentuknya zona lemah yang menghasilkan gempa mikro.

\subsection{Uji Resolusi}

Dapat dilihat bahwa pada penampang horizontal menunjukan resolusi baik pada kedalaman -1 km hingga 1 $\mathrm{km}$ dibawah permukaan laut. Hal tersebut sesuai dengan banyaknya event yang terjadi pada kedalaman -1 sampai $1 \mathrm{~km}$ disebabkan oleh adanya induced event. Sedangkan dibawah $2 \mathrm{~km}$ event yang cenderung lebih sedikit dan menyebar sehingga menyebabkan hasil kurang teresolusi.

Penelitian ini menginterpretasikan hasil tomogram penampang horizontal pada elevasi $-1 \mathrm{~km}$ sampai $1 \mathrm{~km}$ serta penampang vertikal B-B dan 2-2. Hasil tomografi double difference berupa perturbasi Vp, Vs dan nilai absolut Vp/Vs. Skala biru menunjukkan nilai Vp, Vs dan absolut Vp/Vs yang tinggi dan skala merah menunjukan nilai $\mathrm{Vp}$, Vs dan absolut $\mathrm{Vp} / \mathrm{Vs}$ yang rendah.

Interpretasi jenis fluida yang dilakukan mengacu pada studi literatur dari penelitian Gunasekera dkk. (2003), Wang dkk. (1990) dan Londolo dan Sudo (2002). Untuk polapola anomali yang muncul dapat diinterpretasikan sebagai berikut:

Interpretasi untuk penampang horizontal sesuai dengan Tabel 2, pada elevasi $1 \mathrm{~km}$ dibawah permukaan laut nilai perturbasi Vp dan Vs rendah dan memiliki nilai Vp/Vs yang rendah pula. Hal ini menarik karena sesuai interpretasi Tabel 2 zona tersebut dikategorikan sebagai zona tersaturasi uap. Untuk mengetahui dimensi zona tersaturasi uap lebih lanjut dapat dilihat pada penampang vertikal B-B dan 2-2. 
Tabel 2. Pola Anomali Vp, Vs, dan Vp/Vs

\begin{tabular}{|l|l|l|r|l|}
\hline No & Vp & Vs & Vp/Vs & Interpretasi \\
\hline 1 & Rendah & Rendah & Rendah & $\begin{array}{l}\text { Zona tersaturasi } \\
\text { uap }\end{array}$ \\
\hline 2 & Rendah & Rendah & Tinggi & $\begin{array}{l}\text { Zona tersaturasi } \\
\text { air }\end{array}$ \\
\hline 3 & Tinggi & Tinggi & Rendah & $\begin{array}{l}\text { Mineral Drying } \\
\text { atau clay cap }\end{array}$ \\
\hline 4 & Rendah & Rendah & Rendah & Old magma Body \\
\hline 5 & Rendah & Tinggi & Rendah & Bidang retakan \\
\hline
\end{tabular}

Interpretasi hasil tomogram penampang vertikal B-B dan 2-2 mengacu pada Tabel 2. Pada penampang B-B dan 2-2 Gambar 6 dapat dikategorikan menjadi beberapa area. Area 1 (garis putus-putus ungu muda) terjadi penurunan Vp dan Vs diikuti dengan $\mathrm{Vp} / \mathrm{Vs}$ yang rendah merupakan zona tersaturasi uap. Area 2 (garis putus-putus kuning) terdapat kenaikan Vp dan Vs diikuti dengan penurunan Vp/Vs merupakan zona mineral drying atau clay cap. Area 3 (garis putus-putus ungu tua) terdapat penurunan Vp dan Vs diikuti dengan kenaikan $\mathrm{Vp} / \mathrm{Vs}$ merupakan zona tersaturasi air. Area 4 (garis putus-putus hijau) terdapat penurunan $\mathrm{Vp}$ dan $\mathrm{Vs}$ dengan penurunan $\mathrm{Vp} / \mathrm{Vs}$ dikategorikan sebagai old magma body. Area 5 (garis putus-putus abu-abu tua) terdapat penurunan Vp kenaikan Vs dan penurunan Vp/Vs belum dapat dikategorikan, hal ini membutuhkan analisis lebih lanjut untuk mengetahui interpretasi pola anomali.

Berdasarkan kedua penampang dapat diketahui bahwa terdapat zona mineral drying atau clay cap dengan ketebalan $1 \mathrm{~km}$ yang menebal kearah timur (Penampang 1-1) dan utara (Penampang B-B). Pada penampang B-B terdapat zona tersaturasi uap yang berada pada kedalaman 0.5 sampai $1.5 \mathrm{~km}$ dan zona tersaturasi air yang dapat diakibatkan injeksi air pada sumur X. Pada penampang 2-2 terdapat kehadiran zona tersaturasi air yang dapat diakibatkan injeksi air pada sumur X dan Y, terdapat pula kehadiran bodi intrusi yang berada di kedalaman 0 sampai $1.5 \mathrm{~km}$ msl.

ntuk mempermudah pembagian area penulis membuat ilustrasi jenis fluida pada Gambar 8. Terlihat bahwa potensi zona tersaturasi uap berada pada penampang B-B bagian utara, hal ini dapat menjadi data pendukung perusahaan dalam menentukan daerah target eksplorasi selanjutnya.

Keberadaan struktur terlihat pada tomogram Vp penampang B-B dan 2-2. Sesuai dengan struktur dominan yang terletak di lapangan Panas Bumi GoLF yaitu sesar Sumatra searah baratlaut tenggara (Sieh dan Natawidjaya, 2000). Dari hasil tomogram Vp B-B terlihat bahwa terdapat tunjaman struktur/bidang lemah yang memiliki dip kearah selatan.

Berdasarkan Gambar 9 dapat dibuat ilustrasi keberadaan struktur dari kedua penampang tersebut Gambar 10. Penampang struktur dipermukaan yang memiliki arah NWSE memiliki dip kearah selatan sesuai dengan hasil tomogram B-B dan 2-2. Hal ini berkaitan dengan keberadaan Sesar Sumatra pada area tersebut.

Salah satu penyebab terjadinya gempa mikro adalah kegiatan pengeboran eksplorasi pada sumur X. Gempa mikro yang terjadi pada lapangan panas bumi GoLF terjadi peningkatan sejak adanya kegiatan pemboran eksplorasi. Persebaran gempa mikro ini menjadi hal yang menarik a)

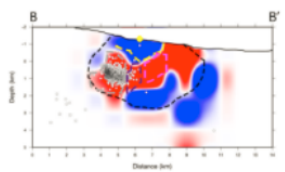

b)
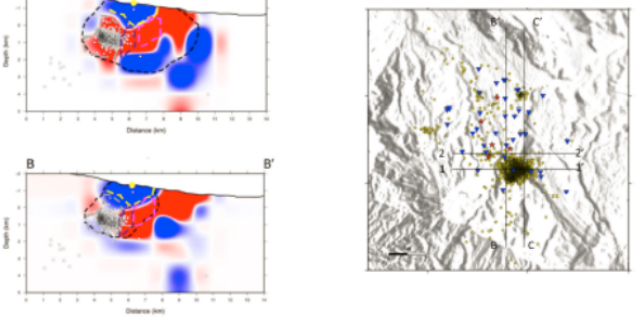

c)
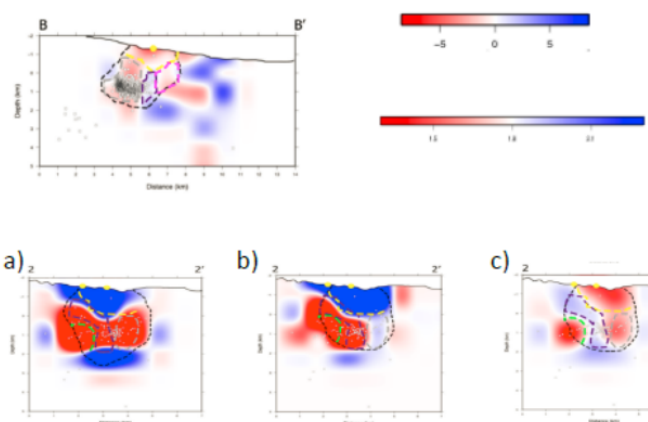

b)
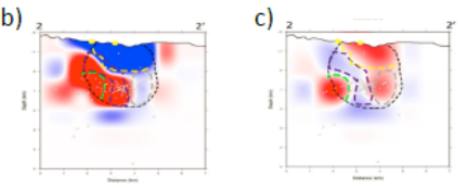

Gambar 7. Interpretasi jenis fluida pada Tomogram a)Vp, b) Vs, dan c) $\mathrm{Vp} / \mathrm{Vs}$ untuk penampang B-B dan 2-2. Area 1 ditandai dengan garis putus-putus ungu muda, area 2 ditandai dengan garis putus-putus kuning, dan area 3 ditandai dengan garis putusputus ungu tua, area 4 ditandai dengan garis putus-putus hijau, dan area 5 ditandai dengan garis putus-putus abu-abu. Bentuk bulat kuning merupakan lokasi sumur bor, bentuk bulat berwarna putih merupakan hiposenter dan garis putus-putus hitam merupakan nilai DWS 500 .
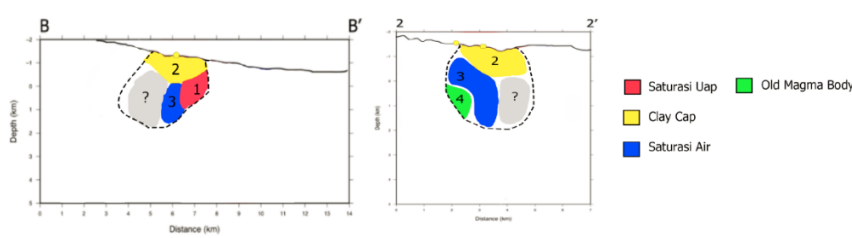

Gambar 8. Ilustrasi untuk interpretasi jenis fluida pada penampang B-B dan 2-2. Bentuk bulat kuning merupakan lokasi sumur bor.

karena memiliki distribusi gempa mikro yang berkumpul dekat dengan titik pemboran dan berfokus pada area tersebut. Kami menginterpretasikan terdapat struktur yang menyebabkan gempa mikro berkumpul pada area tersebut. Struktur tersebut membatasi gempa mikro (boundary) dan dapat dikategorikan sebagai struktur yang bersifat impermeabel. Pada kegiatan pemboran sumur X dari 15 Desember 2012 sampai 28 Januari 2013 terjadi peningkatan gempa mikro yang signifikan akibat pemboran dan tersebar pada area tertentu.

Berdasarkan IESE (2013) terdapat struktur-struktur kecil dengan arah NE-SW pada lapangan panas bumi ini hal ini dapat berkaitan dengan distribusi gempa mikro yang mengindikasikan adanya struktur. Gambar 11 menggambarkan lokasi struktur tersebut.

Kehadiran struktur tersebut dapat terlihat pada penampang 1-1 ditunjukan pada Gambar 12, keberadaan struktur yang ditandai dengan batas antara kecepatan tinggi dan rendah pada tomogram Vp. Secara vertikal terlihat 
a)

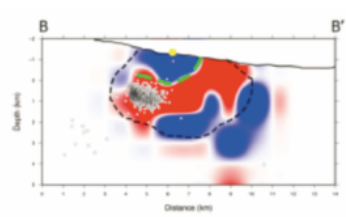

¿)

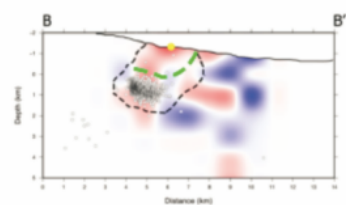

b)
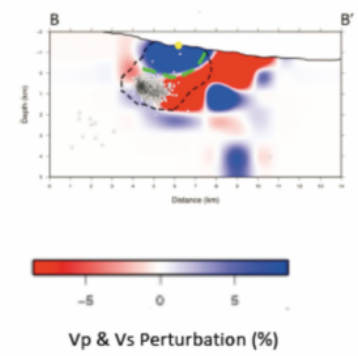

Vp \& Vs Perturbation (\%)

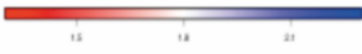

Vp/Vs AbsolutVp/Vs Absolut

Gambar 9. Tomogram a)Vp, b)Vs dan c) Vp/Vs pada penampang B-B dan 2-2. Garis putus-putus hijau merupakan keberadaan struktur. Bentuk bulat kuning merupakan lokasi well, bentuk bulat berwarna putih merupakan hiposenter dan garis putusputus hitam merupakan nilai DWS 500 .

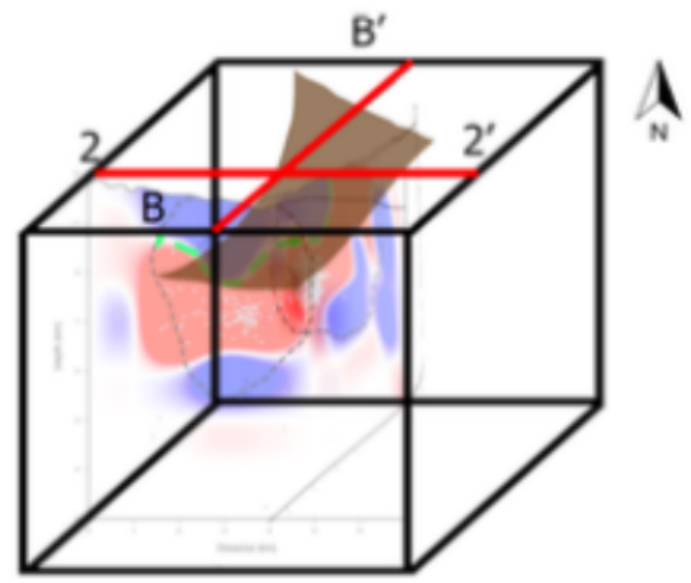

Gambar 10. Ilustrasi keberadaan struktur yang memiliki dip kearah selatan. Garis merah merupakan letak penampang, bidang berwarna coklat merupakan struktur. Sisi depan dan kanan terdapat overlay tomogram Vp penampang 2-2 dan B-B.

struktur tersebut membatasi persebaran hiposenter yang diakibatkan oleh sumur bor X.

\section{KESIMPULAN}

Dari hasil pengolahan data dan interpretasinya, kami mencoba menarik kesimpulan sebagai berikut: (1) Metode Master Event Cross Correlation menghasilkan data waktu tiba gelombang yang lebih akurat. (2) Hasil relokasi hiposenter dengan metode tomografi double difference menunjukkan lokasi hiposenter membentuk kluster di sekitar sumur akibat kegiatan pemboran. (3) Pada penampang B-B dan 2-2 diketahui bahwa lapisan penudung atau clay cap berada dekat permukaan dengan ketebalan $1 \mathrm{~km}$. Terdapat area prospek yang ditandai dengan zona saturasi uap pada penampang B-B kearah utara pada kedalaman $-0.5 \mathrm{~km}$ sampai $1 \mathrm{~km}$. Zona tersaturasi air diakibatkan karena aktifitas pemboran sumur. (4) Terdapat keberadaan struktur NW-SE yang menunjam ke arah selatan dibawah penampang B-B dan struk-

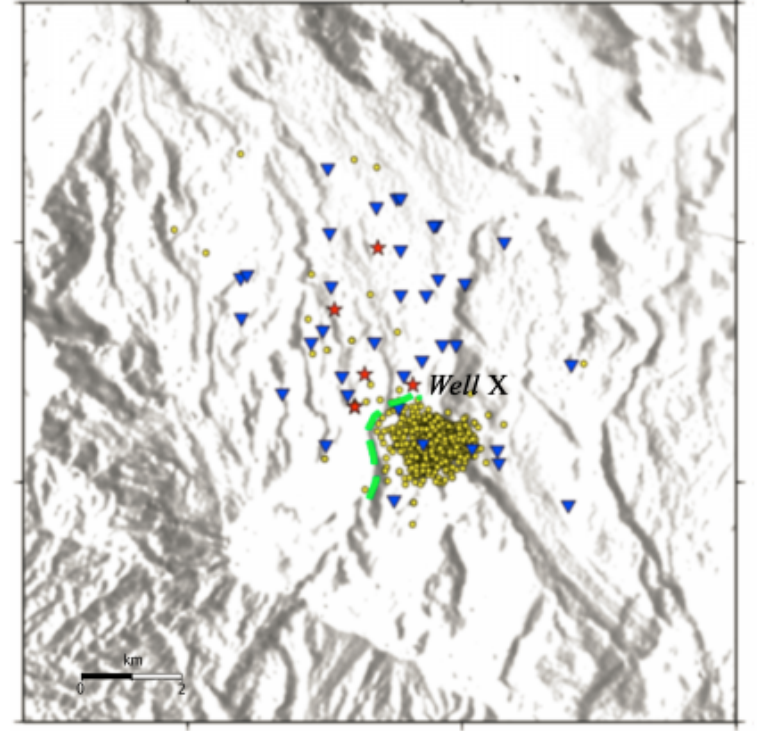

Gambar 11. Lokasi stuktur impermeable. Bulat kuning merupakan episenter gempa, segitiga biru terbalik merupakan stasiun, bintang merah merupakan well, dan garis putus-putus hijau merupakan struktur yang bersifat impermeable.

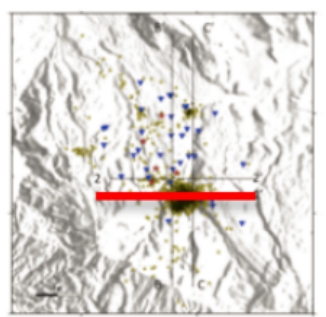

a)

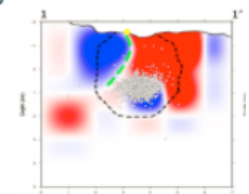

b)
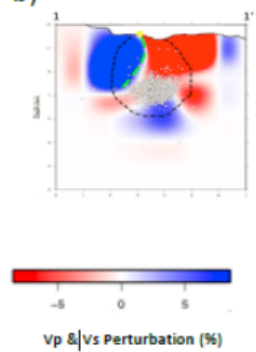

VP \& vs perturbation (\%)

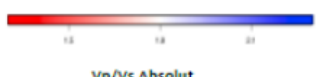

Vp/Vs Absolut c)

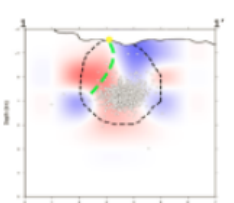

Gambar 12. Keberadaan struktur pada penampang vertikal 1 -1 tomogram a)Vp, b) Vs, dan c) Vp/Vs. Garis hijau putus-putus merupakan keberadaan struktur.

tur yang bersifat impermeable membatasi persebaran gempa mikro saat dilakukan pemboran pada sumur X.

\section{DAFTAR PUSTAKA}

Bettani, P. Goertz-Allmann, D. Kuhn, V. Oye, B. Bohloli, dan E. Aker, 2014. Combining microseismic observations and geome- 
chanical models to interpret storage integrity at the In Salah CCS site. Geophysical Journal International.

Gunasekara, R.C., Foulger, G.R., dan Julian, B.R., 2003. Reservoir depletion at The Geysers geothermal area, California, shown by fourdimensional seismic tomography, J. Geophys. Res., Vol. 109, No. B3, 2134.

I.J., Alfiady, Bogie, I., Nur Izati, C., Azis, H., Hadi, J., 2013. Preliminary Geology Model of Muara Laboh : Facies and Porosity Assessment. Proceedings Indonesia International Geothermal Convention and Exhibition 2013.

Lees, J. M. dan H. Wu, 1999. Poissons ratio and porosity at Coso Geothermal Area, California. Journal of Volcanology and Geothermal Research, 95, 2000, 157-173.

Londono, J.M, Y. Sudo, 2002. Velocity structure and a seismic model for Nevado del Ruiz Volcano (Colombia). J. Volcano. Geotherm. Res. 119, 61-87.

Mori, J., 2008. Determination of dip direction for the 2007 Chuetsu-oki earthquake from relocation of aftershocks using arrival times determined by cross-correlation. Earth Planets Space, vol. 60 , pp. 11171120 .

R. Sanderson, J. Andrews, C. Boese dan A. Lucas, 2013. Final Basic Analysis Report On Muara Laboh Microearthquake Data for Geothermal Driling Targeting. Institut of Earth and Science Engineering.

Rosidi, H.M.D., Tjokrosapoetro, S. dan Pendowo, B., 1996. Geological Map Of The Painan And Northern Part Of The Muara Siberut Quadrangle,Sumatera.Pusat Penelitan Dan Pengembangan Geologi

Saputra, I.J., Alfiady, Bogie, I., Nur Izati, C., Azis, H., Hadi, J., 2013. Preliminary Geology Model of Muara Laboh : Facies and Porosity Assessment. Proceedings Indonesia International Geothermal Convention and Exhibition 2013.

Schaff, D.P. dan Waldhauser, F., 2005. Waveform CrossCorrelation-Based Differential Travel-Time Measurements at the Northern California Seismic Network. Bulletin of the Seismological Society of America, vol. 95, no. 6, pp. 24462461, December 2005, doi: 10.1785/0120040221

Sieh, K dan Natawidjaja, D., 2000. Neotectonics Of The Sumatran Fault, Indonesia. Journal Of Geophysical Research, Vol 105,No.B12, pp. 295-326.

Situmorang. J., Martikno R., Perdana A., Ganefianto, 2014. A Reservoir Simulation of the Muara Laboh Field, Indonesia, Proceedings 41st Workshop on Geothermal Reservoir Engineering Stanford University, Stanford, California, 2016 SGP-TR-209.

Waldhauser, F., 2001. HypoDD: A Program to Compute DoubleDifference Hypocenter Locations(hypoDD version 1.0 - 03/2001). Open File Report 01-113.

Waldhauser, F., dan W. L. Ellsworth. 2000. A double-difference earthquake location algorithm : Method and application to the Northern Hayward Fault, California. Bull. Seism. Soc., 90, 13531368.

Wang, Z., Batzle, Michael L., dan Nur, Amos M., 1990. Effect of different pore fluids on seismic velocities in rock, Can. J. Explor. Geophys., 26(1 dan 2), pp. 104112.

Zhang, H., dan C. H. Thurber., 2003. Users manual for tomoDD 1.1 (double difference tomography) for determining event locations and velocity structure from local earthquake and explosions, draft, University of Wisconsin-Madison.

Zhang, H., dan C. H. Thurber, 2003. Double difference tomography: The method and its application to the Hayward Fault, California: Bull. Seism. Soc. Am., 93,1875-1889. 